\title{
Investigating Rock-Slope Failures in the Tien Shan: State-of-the-Art and Perspectives of International Cooperation (M111)
}

\author{
Alexander L. Strom* • Oliver Korup • Kanatbek E. Abdrakhmatov • Hans-Balder Havenith
}

\begin{abstract}
The Tien Shan is an intracontinental mountain system $\sim 1500 \mathrm{~km}$ long and up to $500 \mathrm{~km}$ wide that formed between the Tarim Basin and the Kazakh Shield due to the India-Asian collision. It is shared by the five nations of Kyrgyzstan, Kazakhstan, Uzbekistan, Tajikistan, and China. As one of the highest and most seismotectonically active parts of the Central Asian Mountain Belt, it is extremely prone to large rock-slope failures. At least nine rock slope failures $>1 \mathrm{~km}^{3}$ in volume, two of which involved $\sim 10 \mathrm{~km}^{3}$, have been identified in the Tien Shan. Thanks to an arid climate many of these formerly river-blocking rockslides and long-runout rock avalanches are well preserved, and both their morphology and internal structure may be readily studied in detail. Here we briefly describe the state-of-the-art and planned future international collaborations in research on rock-slope failures in the Tien Shan.
\end{abstract}

Keywords. Rockslide, rock avalanche, landslide dam, Tien Shan, Kyrgyzstan, landslide hazard and risk

\subsection{Introduction}

The Tien Shan ("Sky Mountains") is one of the highest and most seismically active parts of the Central Asian Mountain Belt (Fig. 12.1). It is shared by the five nations of Kyrgyzstan, Kazakhstan, Uzbekistan, Tajikistan, and
China. Numerous landslides are known here, yet only a small part of them have been described in publications and unpublished technical reports. Landslides in some parts of the Tien Shan have been regularly studied during Soviet times (Fedorenko 1988; Zolotariov 1990; Niazov et al.2002), but even these data are poorly known by landslide researchers outside the former USSR. We expect a similar situation with landslide research in the eastern part of the mountain belt, i.e. the Chinese Tian Shan.

Recently, international cooperation in landslide research started developing in Kyrgyzstan. These activities have been largely stipulated by the significant environmental hazard posed by large active landslides endangering the stability of numerous radioactive mine tailings in the Mailuu-Suu Valley (Aleshin et al. 2002; Torgoev et al. 2002). These investigations, along with some other projects in the densely populated eastern rim of the Fergana Basin, are focused on monitoring and early warning of selected landslides and landslide-prone slopes, which mainly occur in unconsolidated Quaternary or poorly lithified Neogene and Mesozoic sediments.

Also, large rockslides with potential of long runout and forming large natural dams in mountain rivers are wide-
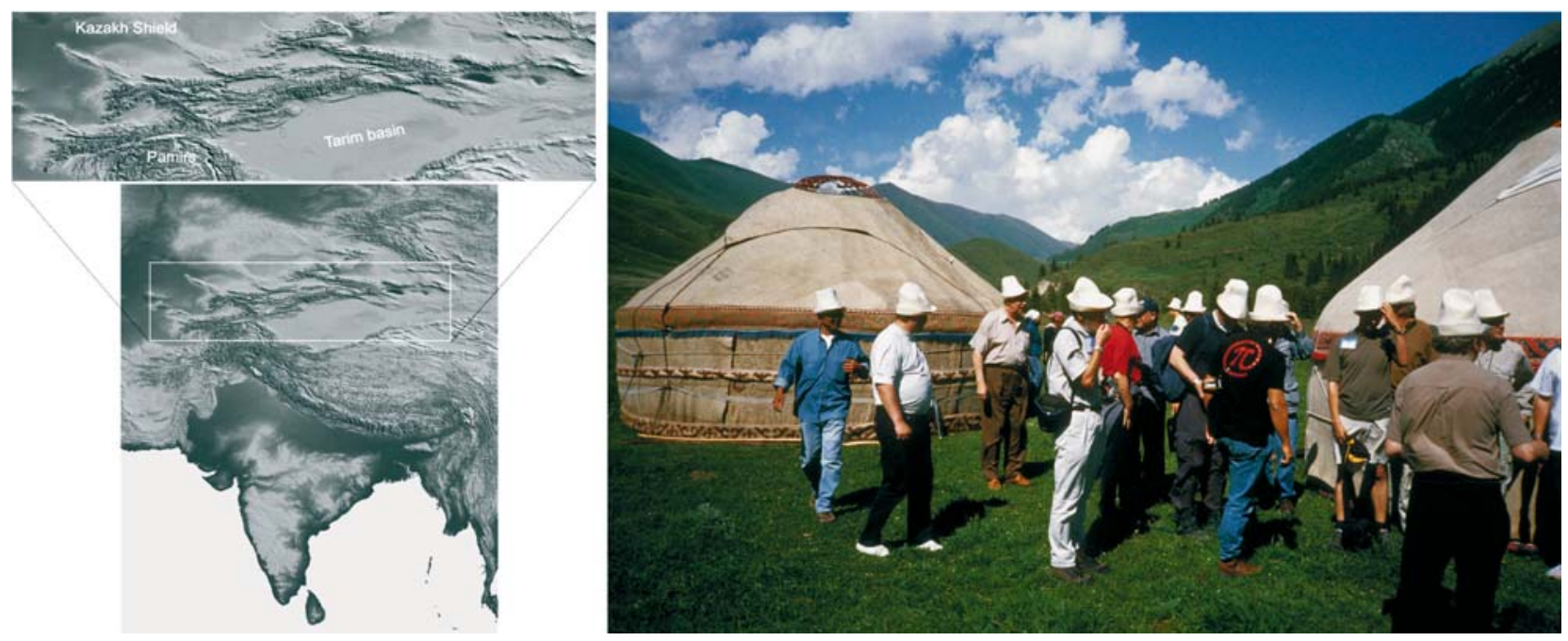

Fig. 12.1. Left: Location of the Tien Shan in the Central Asian region; right: participants of the NATO Advanced Research Workshop on "The Security of Natural and Artificial Rockslide Dams", Kyrgyzstan, June 2004, in front of traditional jurts 
spread in the Tien Shan. They have been studied during the 1960s to 1980s e.g. in the Zeravshan River Basin in the SW (Tajik) Tien Shan (Fedorenko 1988), the central Naryn River Basin in connection with the Toktogul hydropower project (Zolotariov 1990), and the southern Tien Shan, where the catastrophic coseismic Khait rock avalanche killed thousands of people in 1949 (Leonov 1960). Two rockslide dams prone to devastating outburst were studied in northern (Kazakh) part of Tien Shan, and several catastrophic breaches of rockslide-dammed lakes occurred in the 1960s. The most well-known cases were at Issyk Lake east of Almaty, Kazahkstan, and Jashinkul Lake in the southern Tien Shan. More recently, various rockslides were studied in the Naryn Valley upstream from the Toktogul Reservoir, in the Kokomeren Valley, and other parts of the Kyrgyz Tien Shan with special focus on the mechanics of their formation and motion (Strom 1996, 1998).

However, there is as yet no comprehensive landslide inventory comparable to e.g. that of the European Alps (Heim 1932; Abele 1974). Hence, no detailed analysis of the magnitude and frequency, and resulting hazard and risk from landslides in the region is possible up to date.

\subsection{Completed and Ongoing Activities}

One of the first international studies concerned with rockslides was the INCO-COPERNICUS Project PL963202 "Landslides triggered by earthquakes in Kyrgyzstan, Tien Shan" in 1997-2000 (Delvaux et al. 2001; Havenith et al. 2002, 2003). Detailed geophysical and seismological studies were applied to the Ananevo and Kaindy rockslides $\left(>0.5 \times 10^{7} \mathrm{~m}^{3}\right)$ triggered by the $1911 \mathrm{M} 8.2 \mathrm{Kemin}$ earthquake, to investigate why only so few slopes experienced large-scale instability despite strong ground shaking. Surface ruptures of the earthquake were also mapped and studied with geophysical and palaeoseismological methods (Delvaux et al. 2001; Havenith et al. 2000).

A NATO Advanced Research Workshop "Security of Natural and Artificial Rockslide Dams" held in Bishkek, Kyrgyzstan, in June 2004, was the next step in order to introduce the Tien Shan to the international community of rockslide researchers. The meeting convened 48 participants from Austria, Belgium, Canada, China, Germany, Italy, Kyrgyzstan, Mexico, New Zealand, Russia, Switzerland, Tajikistan, UK, and the U.S.A., and included a oneday field trip to the Chon-Kemin Valley, where a cluster of four large prehistoric rockslides had mobilized $\sim 1.2 \mathrm{~km}^{3}$ of rock. Fifteen researchers from Austria, Canada, Germany, Italy, Kyrgyzstan, New Zealand, Russia, Switzerland, and the UK participated in a five-day post-conference field trip during which several large to giant rockslides and rock avalanches were visited and discussed. Most of the rockslide deposits visited are deeply incised by erosion and thus, participants had the opportunity to study their internal structure, lithology, and grain-size composition. Much of the preparatory work for the workshop and field trips was supported by IPL2002 M-111 Project "Detail study of the internal structure of large rockslide dams in the Tien Shan and the International field mission - Internal structure of dissected rockslide dams in Kyrgyzstan". Two field guidebooks were prepared (Strom and Abdrakhmatov 2004a,b) to compile an overview of the most prominent rockslide sites.

\subsection{Aims and Goals of Further Studies}

The NATO Advanced Research Workshop strongly contributed to outlining future key objectives for studying large rock-slope failures and slope-instability in the Tien Shan. The first objective is to systematically compile a regional GIS inventory of rockslides, landslides, and related phenomena (sackungen) across the entire Tien Shan, irrespective of political boundaries. This is the main goal of IPL2004 M-127 Project "Compilation of uniform landslide inventory for the Tien Shan Mountain system" approved by the 2004 ICL BOR meeting in Bratislava. Mapping will be based on the analysis of high-resolution $(<15 \mathrm{~m})$ space images such as KFA-1000, KFA-3000, Corona, SPOT, ASTER, and IRS, allowing detection of most large-scale slope failures with areas $>0.1 \mathrm{~km}^{2}$, and volumes of roughly $>10^{6} \mathrm{~m}^{3}$. Similar studies were done for the Suusamyr Basin and surrounding ranges (Havenith et al. 2003), where several hundreds of landslides have been identified on satellite images, forming the database for slope stability analyses. The largest events can be also identified with satellite imagery draped over 3" SRTM digital elevation data. So far, nine "gigalandslides" $\left(>10^{9} \mathrm{~m}^{3}\right)$ have been identified in the Kyrgyz Tien Shan (Strom and Korup submitted; Korup et al. in press).

Another very important topic of future studies is the absolute dating of rockslides and other geomorphic features such as fault scarps and river terraces that can shed light on the recurrence of rockslide events. This will allow the establishment of magnitude-frequency curves, and, together with limit equilibrium and back analyses, test our currently favored hypothesis that most of the large rock-slope failures in the Tien Shan would be of seismic origin. We have submitted several funding proposals to the European Commission, the Swiss National Science Foundation, and INTAS, for using radiometric $\left({ }^{14} \mathrm{C}\right.$, OSL, and cosmogenic isotopes), dendrochronologic, and lichenometric dating for this purpose.

Process-related research is highly promising, given that excellent exposures along 200-400 m deep river gorges cut into rockslide debris allow studies of landslide internal structure, including grain-size analysis, and mechanical properties of rockslide debris. Another important theme in future studies is the identification of potentially unstable 
rock-slopes prone to catastrophic failure. The phenomenon of rockslide clustering is widely developed in the Tien Shan and shows that even along active fault zones some local areas are subjected to larger and, likely, more frequent bedrock slope failures. These "focal points" will serve as starting points for regional slope-stability analyses.

All these objectives and research issues strongly depend on successful international collaboration. Joint efforts of landslide researchers from countries adjoining the Tien Shan should be directed to allow using harmonized criteria of rockslide selection and classification, as well as exchange of data and expertise. An overall aim will be the promotion of rockslide and landslide hazard and risk assessment across the entire mountain system. In close connection with the above investigations, we are planning an annual international summer school on rockslides and related phenomena for students and young landslide researchers in the Kokomeren Valley, Kyrgyzstan, known for its clustering of several rockslides and rock avalanches (Fig. 12.2). Participants of the summer school will be trained, among others, in methods of bedrock slope failure mapping, absolute dating, detail study of their internal structure, grain-size composition, and geomorphic evidence of rockslide-dam failure.

\subsection{Conclusions}

The Tien Shan provides high potential for studying catastrophic rock-slope failures and their hazard and risk implications before a trans-national background. The arid climate and dense road network in the Tien Shan makes many spectacular landslides sites accessible, that easily rival in size those reported from other mountain belts. Comparison of landslide characteristics and distributions in the Tien Shan with those in seismically less active mountain belts such as the European Alps will also increase our understanding of the role of seismicity in triggering large rock-slope failures.

\section{References}

Abele G (1974) Bergstuerze in den Alpen; ihre Verbreitung, Morphologie und Folgeerscheinungen. Translated title: Alpine landslides; their distribution, morphology, and consequences. Wissenschaftliche Alpenvereinshefte.25, Deutscher Alpenverein, Munich, $230 \mathrm{pp}$

Aleshin YG, Torgoev IA, Shmidt G (2002) Environmental risk management at uranium tailing ponds in Mailuu-Suu, Kyrgyzstan. In: Merkel B, Planer-Friedrich B, Wolkersdorfer C (eds) Uranium in the aquatic environment. Springer-Verlag, Berlin Heidelberg, pp 881-888

Delvaux D, Abdrakhmatov KE, Lemzin IN, Strom AL (2001) Landslides and surface breaks of the 1911, Ms 8.2 Kemin earthquake, Kyrgyzstan. Russ Geol Geophys 42:1583-1592

Fedorenko VS (1988) Landslides and rockfalls in mountains, and their forecasting. Moscow University Press, Moscow

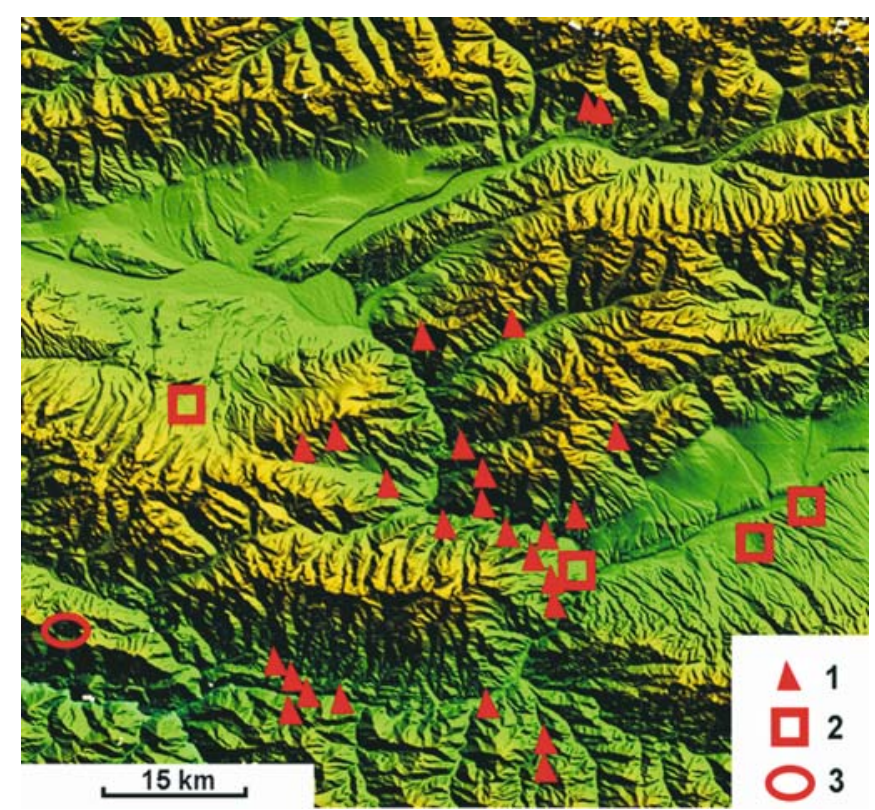

Fig. 12.2. Largest rock slope failures and landslides in the Kokomeren River Basin. 1: Rockslides and rock avalanches $>10^{6} \mathrm{~m}^{3} ; 2$ : largest landslides in Neogene and Quaternary deposits; 3: Caldera-like Kyzylkiol collapse

Havenith H-B, Jongmans D, Abdrakhmatov K, Torgoev I, Delvaux D, Strom A, Trefois P (2000) Application of geophysical methods to seismic landslides and fault scarps in Kyrgyzstan (Central Asia). In: Proc Kyrgyz National Academy of Sciences, Institute of Rock Physics and Mechanics, Bishkek, Kyrgyzstan, pp 173-182

Havenith H-B, Jongmans D, Faccioli E, Abdrakhmatov, K, Bard P-Y (2002) Site effects analysis around the seismically induced Ananevo rockslide, Kyrgyzstan. Bull Seismol Soc Am 92: 3190-3209

Havenith H-B, Strom A, Jongmans D, Abdrakhmatov K, Delvaux D, Tréfois P (2003) Seismic triggering of landslides, part A: Field evidence from the Northern Tien Shan. Natural Hazards and Earth System Sciences 3:135-149

Heim A (1932) Bergsturz und Menschenleben. Beiblatt zur Vierteljahrsschrift der Naturforschenden Gesellschaft in Zürich, vol.77, pp 1-217. Translated by N. Skermer under the title "Landslides and Human Lives", BiTech Publishers, Vancouver, British Columbia, Canada, 1989, 195 pp

Korup O, Strom AL, Weidinger JT (in press) Fluvial response to large rock-slope failures - examples from the Himalayas, the Tien Shan, and the New Zealand Southern Alps. Geomorphology

Leonov NN (1960) Khait earthquake of 1949 and the geological conditions of its occurrence. Geology and Geophysics, Geophysical Series 3:48-56 (in Russian)

Niyazov RA, Nurtaev BS, Minchenko VD (2002) Hazard assessment of geological processes in loess rock of the mountain regions of Uz-bekistan. In: Proc $9^{\text {th }}$ IAEG Congress, Westville (South Africa), $\mathrm{p} 9$

Strom AL (1996) Some morphological types of long-runout rockslides: effect of the relief on their mechanism and on the rockslide deposits distribution. In: Senneset K (ed) Proc $7^{\text {th }}$ International Symposium on Landslides, 1996, Trondheim, Norway, Rotterdam. Balkema, pp 1977-1982 
Strom AL (1998) Giant ancient rockslides and rock avalanches in the Tien Shan Mountains, Kyrgyzstan. Landslide News 11:20-23

Strom AL, Abdrakhmatov KE (2004b) NATO ARW guidebook. Rock avalanches and rockslide dams of the Northern Kyrgyzstan (Kyrgyz Range and Chon-Kemin River Valley)

Strom AL, Abdrakhmatov KE (2004c) Post-ARW field trip guidebook. Rockslides and rock avalanches of the Kokomeren River Basin and Karakudjur rockslide
Strom AL, Korup O (submitted) Extremely large rockslides and rock avalanches in the Tien Shan, Kyrgyzstan. Landslides

Torgoev IA, Alioshin YG, Aitmatov IT (2002) Danger and risk of natural and man-caused disasters in mountains of Kyrgyzstan. In Aidaraliev et al. (eds) Mountains of Kyrgyzstan. Bishkek Publishing House "Technology", Bishkek, pp 157-166

Zolotarev GS (1990) Methodology of engineering-geological investigations. Moscow State University Publishers. 384 p 